\title{
EVALUATION OF METHODS FOR THE DETERMINATION OF O AND K ANTIGENS OF AN O2:K1(L) STRAIN OF ESCHERICHIA COLI
}

\author{
J. R. Deb and E. G. Harry \\ Houghton Poultry Research Station, Houghton, Huntingdon, Cambridgeshire PE17 2DA
}

In the existing serological classification of Escherichia coli, based on the heat stabilities of the $\mathrm{K}$ (capsular) and $\mathrm{O}$ (somatic) antigens, the presence of $\mathrm{K}$ antigens is determined by the agglutinability or inagglutinability of unheated cells in $\mathrm{O}$ and $\mathrm{OK}$ antisera. Thus, the presence of a $\mathrm{K}$ antigen should be indicated in a bacterial agglutination test by the inagglutinability of unheated cells in $\mathrm{O}$ antiserum of the same serogroup, and $\mathrm{O}$ agglutinability should indicate the absence of a $\mathrm{K}$ antigen. It should be possible to confirm these results by demonstrating the presence or absence of bacterial agglutination when the unheated cell suspension is incubated with $\mathrm{OK}$ or $\mathrm{K}$ antiseru mat $37^{\circ} \mathrm{C}$. The agglutinated bacteria normally form floccules on dispersal, but with $\mathrm{K}$ antigens of the $\mathrm{L}$ type, which are generally poor agglutinogens, $\mathrm{K}$ agglutination is described as "granular" (Kauffman, 1966). The presence of $\mathrm{O}$ antigens, on the other hand, is determined by heating cells at $100^{\circ} \mathrm{C}$ and incubating them with either $\mathrm{O}$ or $\mathrm{OK}$ antiserum at $50^{\circ} \mathrm{C}$.

In our experience, bacterial agglutination tests made with the strains of serogroups $\mathrm{O} 1$ and $\mathrm{O} 2$, which have an $\mathrm{L}$ type of $\mathrm{K} 1$ antigen, showed that $\mathrm{O}$ inagglutinability was not always correlated with the subsequent demonstration of $\mathrm{K}$ agglutinins; in some cases, K-agglutination titres were obtained with $\mathrm{O}$-agglutinable colonies and vice versa. This occurred with strains maintained as stock cultures and with fresh isolates from septicaemic chickens. Furthermore, the agglutination with $\mathrm{OK}$ and $\mathrm{K}$ antisera was either floccular or granular; and, in the granular type, it was often difficult to determine the exact titre. In contrast, determination of the $\mathrm{O}$ antigen presented no problems.

These observations support the view that the identification and classification of $\mathrm{K}$ antigens by bacterial agglutination tests is unreliable (Ørskov and Ørskov, 1970), and should be supplemented by the use of more sophisticated techniques, such as indirect haemagglutination, immunodiffusion and immunoelectrophoresis. The following account compares the traditional agglutination tests with these other methods for the determination of the $\mathrm{K} 1$ antigen associated with serogroup $\mathrm{O} 2$.

\section{MATERIALS AND METHODS}

Strain examined. E. coli strains of serogroup $\mathrm{O} 2$ are most commonly associated with the disease " coli septicaemia" in chickens (Harry, 1964) and all these strains have the K1 antigen (Edwards and Ewing, 1954; Sojka and Carnaghan, 1961). The strain investigated (no. HPRS1318) was isolated from a typical outbreak of the disease and had been kept at 
$4^{\circ} \mathrm{C}$ since 1964 on Dorset-egg slopes with frequent subcultures. Ten colonies from a bloodagar culture were studied, to take account of the possible occurrence of V-W form variation within colonies of a culture (Kauffmann, 1943). These were subcultured on Dorset-egg slopes. In all cases, cultures were incubated at $37^{\circ} \mathrm{C}$. In the Results section the term " colony " refers to subcultures of the colony specified.

Antigen extracts. Growth from the Dorset-egg slopes was incubated for $7 \mathrm{~h}$ in Nutrient Broth (Oxoid) and subcultured for $20 \mathrm{~h}$ on D5-agar medium (Schlecht and Westphal, 1966) in Roux flasks. The growth from each flask was harvested in $10 \mathrm{ml}$ of phosphate-buffered saline (PBS, $p \mathrm{H} \mathrm{7.2)}$ and cell extracts were prepared by each of the following methods: (1) the cell suspension was heated at $60^{\circ} \mathrm{C}$ for $20 \mathrm{~min}$., centrifuged and the supernate collected (" $60^{\circ}$ extract "); (2) a portion of the $60^{\circ}$ extract was heated at $100^{\circ} \mathrm{C}$ for $1 \mathrm{hr}$ (" $60^{\circ} / 100^{\circ}$ extract "); (3) the cell suspension was heated at $100^{\circ} \mathrm{C}$ for $1 \mathrm{~h}$, centrifuged and the supernate collected (" $100^{\circ}$ extract"). The first two extracts corresponded to those described by Ørskov et al. (1971) and the last to that described by Sojka (1965). The extracts were freeze-dried and reconstituted by dissolving a standard quantity in the diluent appropriate for the test to be performed (see below).

Antisera. $\mathrm{O}$ and $\mathrm{OK}$ antisera were prepared by injecting the homologous strain (HPRS1318) into rabbits (Ewing, 1963). The O suspension was prepared from a 7-h broth culture that had been heated for $2 \frac{1}{2} \mathrm{~h}$ at $100^{\circ} \mathrm{C}$, and the $\mathrm{OK}$ suspension from an untreated 7-h broth culture freshly prepared for each injection. The $\mathrm{K}$ antiserum was produced by diluting the $\mathrm{OK}$ antiserum 1 in 10 and absorbing twice with cell suspensions heated at $100^{\circ} \mathrm{C}$ for $2 \frac{1}{2} \mathrm{~h}$ (Edwards and Ewing, 1962).

Bacterial agglutination $(B A)$ and $O$-inagglutinability tests. The $\mathrm{O}$-antigen suspension was prepared by adjusting a 7-h broth culture to contain $c .1 .5 \times 10^{9}$ cells per ml, heating for $1 \mathrm{~h}$ at $100^{\circ} \mathrm{C}$ and adding formalin $(0.3 \% \mathrm{v} / \mathrm{v})$. The suspension was stored at room temperature until required. The $\mathrm{K}$-antigen suspension was prepared by incubating the strain overnight on glucose-agar slopes $(0.1 \% \mathrm{w} / \mathrm{v}$ glucose $)$, washing off the growth with mercuric iodide solution $(0.1 \% \mathrm{w} / \mathrm{v})$ and adjusting the suspension to contain $c .4 .5 \times 10^{9}$ cells per ml. This was freshly prepared for each test. A similar suspension, but in PBS, was used for the $\mathrm{O}$-inagglutinability test with a 1 in 50 dilution of $\mathrm{O}$ antiserum. The determination of $\mathrm{O}$ and $\mathrm{K}$ agglutinins and the test for $\mathrm{O}$ inagglutinability were made as described by Kauffmann (1966).

Indirect haemagglutination $(I H A)$ test. Two mg of the appropriate extract were dissolved in $1 \mathrm{ml}$ of serum diluent and the test was carried out as described by Cruickshank (1965), except that: (1) a $0.002 \%(\mathrm{w} / \mathrm{v})$ solution of tannic acid was used to prepare the tanned erythrocytes, (2) $3 \%(\mathrm{v} / \mathrm{v})$ of normal rabbit serum in PBS was used as the serum diluent with

TABLE I

Agglutination of culture suspensions from different colonies of Escherichia coli O2:K1 with $O K$ and $K$ antisera

\begin{tabular}{|c|c|c|c|c|c|c|c|c|c|c|c|}
\hline \multirow{2}{*}{ Antigen } & \multirow{2}{*}{ Antiserum } & \multicolumn{10}{|c|}{ Agglutination titres with colony no.* } \\
\hline & & 1 & 2 & 3 & 4 & 5 & 6 & 7 & 8 & 9 & 10 \\
\hline $\begin{array}{l}\mathrm{O} \\
\mathrm{K} \\
\mathrm{K} \\
\mathrm{K}\end{array}$ & $\begin{array}{l}\text { OK } \\
\text { OK } \\
\mathrm{K}_{\ddagger}^{\ddagger} \\
\mathrm{K}_{\dagger}\end{array}$ & $\begin{array}{r}1280 \\
640 \\
0 \\
160\end{array}$ & $\begin{array}{c}1280 \\
160 \dagger \\
0 \\
40\end{array}$ & $\begin{array}{r}1280 \\
160 \\
160 \\
640\end{array}$ & $\begin{array}{c}1280 \\
320 \dagger \\
160 \\
640\end{array}$ & $\begin{array}{r}5120 \\
20 \\
160 \\
640\end{array}$ & $\begin{array}{r}5120 \\
20 \\
160 \\
640\end{array}$ & $\begin{array}{r}1280 \\
160 \\
0 \\
160\end{array}$ & $\begin{array}{r}1280 \\
640 \\
160 \\
1280\end{array}$ & $\begin{array}{r}5120 \\
20 \\
160 \\
1280\end{array}$ & $\begin{array}{r}1280 \\
320 \\
160 \\
1280\end{array}$ \\
\hline
\end{tabular}

* Colonies nos. 2 and 3 were $O$ inagglutinable.

$\dagger$ Granular agglutination on dispersal.

‡ Floccular agglutination on dispersal.

Floccular and granular agglutination were recorded separately in the same tests with $\mathrm{K}$ antigen and $K$ antiserum. 
tanned erythrocytes, (3) PBS supplemented with $0 \cdot 1 \%$ (w/v) of gelatin (Kabat and Mayer, 1961) was used as the serum diluent with normal erythrocytes, (4) $0.3 \mathrm{ml}$ of the erythrocyte suspension was incubated with the same volume of diluted antiserum in the haemagglutination test. Control tests consisting of unsensitised erythrocytes with undiluted antiserum and sensitised erythrocytes with serum diluent were included to exclude the presence of nonspecific agglutination.

Immunodiffusion (ID) test. Difco Noble Agar (1.5\% w/v), dissolved in PBS and supplemented with $10 \%(\mathrm{v} / \mathrm{v})$ of horse serum (Wellcome no. 3), (Hanson, 1959), was poured on $80 \times 80$-mm glass slides to obtain an agar layer c. $1.5 \mathrm{~mm}$ in thickness (Mancini, Carbonara and Heremans, 1965). The slides were stored for 2 days in a humid atmosphere before the test. Rectangular wells $(2 \times 6 \mathrm{~mm}$ and $5 \mathrm{~mm}$ apart $)$ were cut in the agar and sealed at the base; these were filled with the appropriate reactants and the slides were incubated at $30^{\circ} \mathrm{C}$ in a humid atmosphere. The appearance of the precipitation lines was recorded daily for 2-3 days after which the lines were stained with amido black and mounted with Bedacryl (E. Gurr Ltd, London).

Immunoelectrophoresis (IE) test. Immunoelectrophoresis was performed on microscope slides with a Shandon electrophoresis apparatus (Model U77, Shandon Scientific Company, London) and $3 \%(\mathrm{w} / \mathrm{v})$ Ionagar no. 3 (Oxoid) diluted 1 to 1 before use with veronal buffer $(p \mathrm{H} 8.2,0.05 \mathrm{M})$. The wells were filled with antigen extracts, and electrophoresis was performed at a constant current of $25 \mathrm{~mA}$ for $1 \mathrm{~h}$, after which the trough was filled with $\mathrm{O}$ or $\mathrm{OK}$ antiserum. The gel was incubated at $30^{\circ} \mathrm{C}$ in a humid atmosphere, and the development of the precipitin lines was recorded after 16-24 h. For a permanent record, the gels were stained as described for the ID test. For both ID and IE tests, $20 \mathrm{mg}$ of the appropriate extract were dissolved in $1 \mathrm{ml}$ of PBS.

\section{RESULTS \\ $O$-inagglutinability and bacterial agglutination tests}

Only two of the 10 colonies examined were $\mathrm{O}$ inagglutinable with $\mathrm{O}$ antiserum (i.e., apparently $\mathrm{K}$ positive); both of these were agglutinated with $\mathrm{OK}$ and $\mathrm{K}$ antisera. Of the eight $\mathrm{O}$-agglutinable colonies (i.e., apparently $\mathrm{K}$ negative) five colonies gave agglutination titres $>160$ with OK antiserum, and

TABLE II

Indirect haemagglutination of erythrocytes sensitised with $60^{\circ}, 60^{\circ} 1100^{\circ}$ and $100^{\circ}$ extracts of $E$. coli O2:KI with different antisera

\begin{tabular}{|c|c|c|c|c|}
\hline \multirow{2}{*}{ Erythrocytes } & \multirow{2}{*}{ Extract* } & \multicolumn{3}{|c|}{ Range of titres with antiserum } \\
\hline & & OK & O & $\mathbf{K}$ \\
\hline Normal sensitised & $\begin{array}{l}60^{\circ} \\
60^{\circ} / 100^{\circ} \\
100^{\circ}\end{array}$ & $\begin{array}{l}1280-2560 \\
5120 \\
2560 \dagger\end{array}$ & $\begin{array}{l}20 \\
5120 \\
1280-2560 \dagger\end{array}$ & $\begin{array}{c}320-640 \\
20 \\
\ldots\end{array}$ \\
\hline Tanned sensitised & $\begin{array}{l}60^{\circ} \\
60^{\circ} / 100^{\circ} \\
100^{\circ}\end{array}$ & $\begin{array}{c}640-1280 \\
\ldots \\
\ldots\end{array}$ & $\begin{array}{l}20 \\
20 \\
\quad \ldots\end{array}$ & $\begin{array}{c}320-640 \dagger \\
20 \dagger \\
\ldots\end{array}$ \\
\hline
\end{tabular}

J. MED. MICROBIOL.-VOL. 10 (1977) 
all gave agglutination titres $>160$ with $\mathrm{K}$ antiserum (table I). These results demonstrated the lack of correlation between $O$ inagglutinability and the demonstration of $\mathrm{K}$ agglutinins; and considerable variation between the $\mathrm{K}$ agglutination titres obtained with $\mathrm{OK}$ and $\mathrm{K}$ antisera and individual colonies was apparent. Furthermore, the $\mathrm{K}$ agglutination was floccular or granular; the former type of agglutination was present mainly in low dilutions of serum while the latter occurred mainly in high dilutions of serum. Unlike the $\mathrm{K}$ agglutination titres, the $\mathrm{O}$ titres with $\mathrm{OK}$ antiserum were consistently high for all colonies.

\section{Indirect haemagglutination tests}

All 10 colonies gave high agglutination titres with $\mathrm{OK}$ but not with $\mathrm{O}$ antiserum in tests with normal sheep erythrocytes sensitised with $60^{\circ}$ extracts. In contrast, all colonies gave equally high agglutination titres with both antisera when normal sheep erythrocytes were sensitised with either $60^{\circ} / 100^{\circ}$ or $100^{\circ}$ extracts (table II). These results demonstrated that the $\mathrm{K} 1$ polysaccharide antigen in the $60^{\circ}$ extract inhibited agglutination of the $\mathrm{O}$ antigen with $\mathrm{O}$ antiserum. The heat-labile nature of the $\mathrm{K} 1$ antigen was indicated because the inhibition of agglutination with $O$ antiserum was absent from the $60^{\circ} / 100^{\circ}$ and $100^{\circ}$ extracts, which gave similar high $\mathrm{O}$-agglutination titres with both $\mathrm{O}$ and $\mathrm{OK}$ antisera; this was confirmed by the high agglutination titres of the $60^{\circ}$ but not the $60^{\circ} / 100^{\circ}$ extracts with the $\mathrm{K}$ antiserum. Furthermore, in tests with tanned erythrocytes sensitised with the $60^{\circ}$ extract, all colonies gave high agglutination titres with $\mathrm{OK}$ but not with $\mathrm{O}$ antiserum; these results indicated the presence of an additional protein antigen in the $60^{\circ}$ extract. The heat-labile nature of this antigen was demonstrated by the marked reduction of titres with

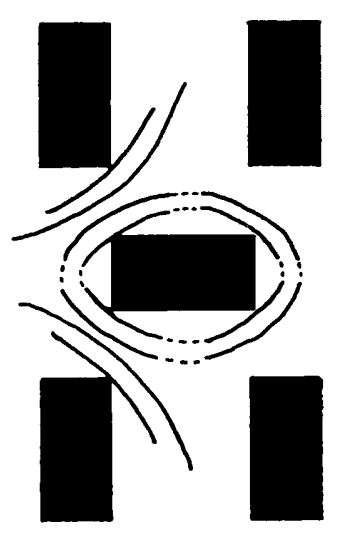

(a)

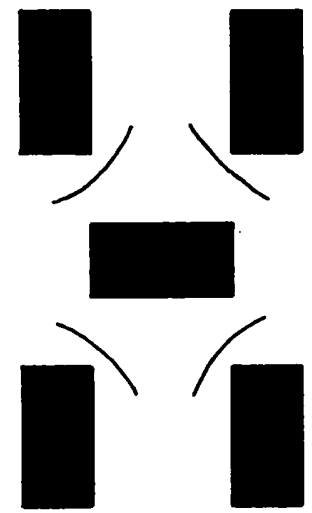

(b)

FIG. 1.-Results of immunodiffusion tests: $(a)$ with $\mathrm{OK}$ antiserum, and $(b)$ with $\mathrm{O}$ antiserum; in each test, the two wells on the left contain $60^{\circ}$ extract and those on the right $60^{\circ} / 100^{\circ}$ extract, and the antiserum is in the central well. 
the $\mathrm{K}$ antiserum when tanned erythrocytes were sensitised with $60^{\circ} / 100^{\circ}$ extracts (table II).

\section{Immunodiffusion test}

The $60^{\circ}$ extracts of all 10 colonies produced four precipitation lines with $\mathrm{OK}$ antiserum of which the line nearest the antigen well was more sharply defined than the others (fig. 1); the $60^{\circ} / 100^{\circ}$ extracts of all colonies produced two lines with OK antiserum, both of which were diffuse and joined the two lines produced by the $60^{\circ}$ extract nearest the antiserum well. In contrast, both extracts produced only one line with $\mathrm{O}$ antiserum. Therefore, the antigenic differences between the two extracts were clearly demonstrated with OK but not with $\mathrm{O}$ antiserum, and the results with $\mathrm{OK}$ antiserum indicated the presence of two extra components in the $60^{\circ}$ extract.

\section{Immunoelectrophoresis test}

The $60^{\circ}$ extracts of all 10 colonies produced two anodic and one to three cathodic precipitation lines with OK antiserum; but only the cathodic lines were formed with $\mathrm{O}$ antiserum (fig. 2). The long anodic line was not completely separated from the cathodic precipitation lines and formed a distinct spur with one of them. These results indicated the presence of two antigens carrying non-identical but serologically related determinants (Ouchterlony, 1958). The

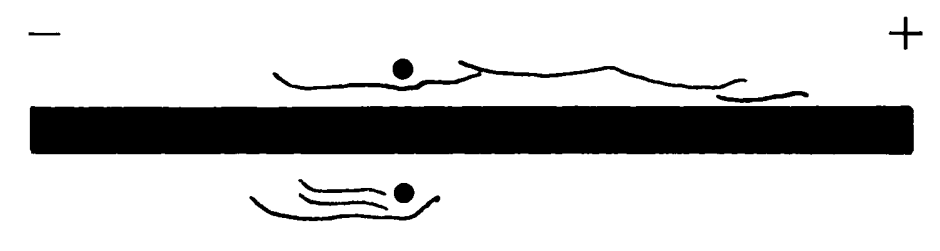

(a)

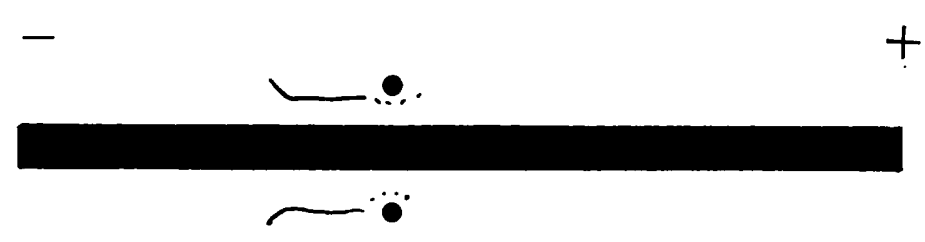

(b)

FIG. 2.-Results of immunoelectrophoresis tests: (a) with $\mathrm{OK}$ antiserum, and $(b)$ with $\mathrm{O}$ antiserum; in each test the upper well contains $60^{\circ}$ extract and the lower well $60^{\circ} / 100^{\circ}$ extract, and the antiserum is in the central trough. 
shape of the lines showed some variation in different tests with $\mathrm{OK}$ antiserum though the pattern was basically similar. In contrast, the $60^{\circ} / 100^{\circ}$ extracts of all colonies produced only the cathodic lines with both antisera but, as with the $60^{\circ}$ extracts, one to three cathodic lines were produced by $60^{\circ} / 100^{\circ}$ extracts with $\mathrm{OK}$ antiserum. The lines with $\mathrm{O}$ antiserum were less distinct than with $\mathrm{OK}$ antiserum with both of the extracts.

\section{Discussion}

Our observation that five colonies of an $\mathrm{O} 2: \mathrm{K} 1$ strain of $E$. coli were $\mathrm{O}$ agglutinable, but gave high $\mathrm{K}$-agglutination titres with both $\mathrm{K}$ and $\mathrm{OK}$ antisera demonstrated the lack of correlation between the O-inagglutinability test and the BA test. Similar findings led Ørskov (1956) to conclude that agglutination of living cultures by $\mathrm{O}$ antiserum does not necessarily indicate the absence of $\mathrm{K}$ antigens. Furthermore, $\mathrm{O}$ inagglutinability can be caused by factors such as fimbriae, flagella (Ørskov et al., 1971) and unidentified heatlabile factors (Jann et al., 1970). Thus, O agglutinability may be determined by the distribution of the $\mathrm{K}$ antigens over the cell surface.

Some variations were also observed in the K-agglutination titres with different antisera and colonies. Three colonies gave high agglutination titres with $\mathrm{K}$ antiserum only, whereas another colony gave high agglutination titres with $\mathrm{OK}$ antiserum only. There are two possible causes for this variation: (1) the difficulty in determining the end point of a titration in which agglutination is granular and (2) the quantitative differences in $\mathrm{K}$ antigen that can occur between different cultures of the same strain (Vahlne, 1945). The appearance of granular agglutination and floccular agglutination in the same $\mathrm{K}$ titration suggests that the nature of the agglutination is determined by the ratios of antigen to antibody and should not be recognised as a characteristic of the L type of K antigen (Kauffman, 1966). It seems, therefore, that the BA test is also unreliable for determination of the $\mathrm{K}$ antigen because the titres with $\mathrm{OK}$ and $\mathrm{K}$ antisera varied with different colonies (table 1). All colonies gave consistently high titres in O-agglutination tests, indicating the uniform distribution of the $\mathrm{O}$ antigen on the cell surface.

In contrast to the agglutination tests, the IHA test gave consistent results. Haemagglutination with $60^{\circ}$ extracts from all colonies and $\mathrm{OK}$ but not $\mathrm{O}$ antiserum demonstrated the presence of the $\mathrm{K} 1$ antigen, and the similar high titres in tests with $60^{\circ} / 100^{\circ}$ and $100^{\circ}$ extracts with both antisera indicated the heat-labile nature of this polysaccharide antigen (Ørskov and Ørskov, 1970). Agglutination of $60^{\circ}$ extracts with $\mathrm{K}$ antiserum that did not occur with $60^{\circ} / 100^{\circ}$ extracts confirmed the presence of this heat-labile $\mathrm{K} 1$ antigen.

The IHA test also demonstrated the presence of a protein antigen in all colonies; the agglutination of sensitised tanned erythrocytes by $60^{\circ}$ extracts with $\mathrm{OK}$ and $\mathrm{K}$ antisera and the absence of agglutination with $60^{\circ} / 100^{\circ}$ extracts indicated that the antigen was heat labile. This agrees with the suggestion that an additional protein $\mathrm{K}$ antigen is present in strains possessing the polysaccharide K1 antigen (Ørskov et al., 1971). 
The presence of these $\mathrm{K}$ antigens indicates that the low agglutination titres of $60^{\circ}$ extracts with $\mathrm{O}$ antiserum was due to inhibition of the binding between $\mathrm{O}$ antigen and antibody by $\mathrm{K}$ antigen, (Landy and Cappellini, 1955); the low agglutination titres of $60^{\circ}$ extracts with $\mathrm{O}$ antiserum was not due to the absence of $\mathrm{O}$ antigen in the extract because the $60^{\circ} / 100^{\circ}$ and $100^{\circ}$ extracts produced similar $\mathrm{O}$ titres with both $\mathrm{OK}$ and $\mathrm{O}$ antisera.

The presence of $\mathrm{O}$ antigen in the $60^{\circ}$ extract was also demonstrated in the ID test with $\mathrm{OK}$ antiserum by the fusion of the two precipitation lines with those of the $60^{\circ} / 100^{\circ}$ extract; this was confirmed in the IE test, where one to three cathodic lines representing the $O$ antigen (Ørskov et al., 1971), were produced by both extracts with the OK antiserum. Similarly, the single cathodic line produced by both extracts with $\mathrm{O}$ antiserum in the ID and IE tests represented the $\mathrm{O}$ antigen. The formation of more than one line representing the $\mathrm{O}$ antigens with $\mathrm{OK}$ but not with $\mathrm{O}$ antiserum suggests that the $\mathrm{O}$ antigen complex was degraded by heating (Rude and Goebel, 1962; Work, 1971) so that cell components lost their ability to stimulate antibody formation but retained their ability to react with antibody.

Two independent lines were formed by the $60^{\circ}$ extract with $\mathrm{OK}$ antiserum in the ID test; one represented the polysaccharide $\mathrm{K} 1$ antigen, and this was confirmed by the production of a long anodic line with the same antiserum in the IE test. Most polysaccharide $\mathrm{K}$ antigens produce this line in the IE test (Ørskov and Ørskov, 1970). However, the K1 line had two peaks similar to those commonly observed with the precipitin line of $\gamma$-globulin (Hirschfeld, 1960). This suggests that the antigen has molecules of different electrophoretic mobilities but identical or partially shared immunological properties (Clausen, 1969). Therefore, the polysaccharide K1 antigen appeared to be heterogenous; this may explain in part the cross-reactions between $E$. coli and other gramnegative organisms (Scheerson et al., 1972). The K1-precipitin line was rarely completely separated from the $\mathrm{O}$-antigen line but in most cases formed a distinct spur at the point of fusion. This indicates the presence of serologically-related determinants in the $\mathrm{O}$ and $\mathrm{K}$ antigens (Ouchterlony, 1958), and may also explain the variable shape of the precipitation lines in different tests with the $60^{\circ}$ extract and $\mathrm{OK}$ antiserum. The short and faint anodic line, adjacent to the $\mathrm{K} 1$-precipitation line, may represent the protein $\mathrm{K}$ antigen, but this requires further investigation with a specific antigen extract. A protein $\mathrm{K}$ antigen has been detected in a strain of serogroup O4 with tanned erythrocytes (Ørskov and Ørskov, 1970); but this was not demonstrated by an IE test.

The present investigation has confirmed that the O-inagglutinability and bacterial agglutination tests are not adequate for determining the $\mathrm{K}$ antigens of $E$. coli (Ørskov and Ørskov, 1970). It has also shown that the K1 antigen may be retained on storage and that form variation of the $\mathrm{K} 1$ antigen of this strain did not occur in the 10 colonies investigated.

\section{SUMMARY}

Tests made on ten colonies from a strain of Escherichia coli $\mathrm{O} 2$ :K1 demonstrated that bacterial agglutination tests were reliable for identifying the $\mathrm{O}$ 
antigen of serogroup $\mathrm{O} 2$ but were unreliable for identifying the $\mathrm{K} 1$ antigen. The granular nature of $\mathrm{K}$ agglutination was not a reliable characteristic of the $\mathrm{L}$ type of $\mathrm{K}$ antigen. In contrast, indirect haemagglutination, immunodiffusion and immunoelectrophoresis tests with bacterial extracts gave consistent results with all colonies. The polysaccharide $\mathrm{K} 1$ antigen formed a long anodic precipitation line with two peaks, indicating its heterogenous nature, and partial fusion of this line with the O-antigen precipitation line suggested the presence of common serological determinants. In addition, a heat-labile protein antigen, possibly another $\mathrm{K}$ antigen, was identified by indirect haemagglutination tests and may have produced a short anodic precipitation line. The results also showed that the $\mathrm{K} 1$ antigen was still produced after storage of a culture for 12 years on Dorset-egg medium.

We are grateful to Mrs Margaret Giddings for her capable technical assistance. We also thank Dr P. M. Biggs, Dr H. Williams Smith, Mrs Hilde Williams and Mr Richard Sampson for assistance in a variety of ways.

\section{REFERENCES}

Clausen, J. 1969. Immunochemical techniques for the identification and estimation of macromolecules. In Laboratory techniques in biochemistry and molecular biology, vol. 1, edited by T. S. Work and E. Work, Amsterdam, p. 470.

Cruickshank, R. 1965. Medical microbiology, 11th ed., Edinburgh and London, p. 919.

EDWARDS, P. R. AND EwING, W. H. 1954. Studies on a coliform type isolated from the organs of fowls. Cornell Vet., 44, 50.

EDWARds, P. R. AND EwING, W. H. 1962. Identification of Enterobacteriaceae, 2nd ed., Minneapolis, Minn., p. 37.

EwING, W. H. 1963. Production of E. coli antisera. In Isolation and identification of Escherichia coli serotypes associated with diarrheal diseases, by W. H. Ewing, Communicable Diseases Center, Atlanta, Ga.

HANSON, L. A. 1959. Immunological analysis of streptococcal antigens and human sera by means of diffusion-in-gel methods. Int. Archs Allergy appl. Immun., 14, 279.

HARRY, E. G. 1964. A study of 119 outbreaks of coli-septicaemia in broiler flocks. Vet. Rec., 76, 443.

HiRsCHFELD, J. 1960. Characterization of precipitating components in normal human sera obtained by an immuno-electrophoretic technique. Acta path. microbiol. scand., 49, 255.

JANN, B., JANN, K., SchmidT, G., ØRSKOV, I. AND ØRSKov, F. 1970. Immunochemical studies of polysaccharide surface antigens of Escherichia coli $0100: \mathrm{K}$ ?(B):H2. Eur. J. Biochem., 15, 29.

Kabat, E. A. AND MAYER, M. M. 1961. Experimental immunochemistry, 2nd ed., Springfield, Illinois, p. 149.

Kauffman, F. 1943. Über neue Thermolabile Körper-Antigene der Coli-Bakterien. Acta path. microbiol. scand., $20,21$.

Kauffmann, F. 1966. The bacteriology of Enterobacteriaceae, Copenhagen, p. 30.

LANDY, M. AND CEPPEllini, R. 1955. Production of " $O$ inagglutinability" in erythrocytes coated with Vi and $\mathrm{O}$ antigens. Nature, Lond., 176, 1266.

Mancini, G., Carbonara, A. O. AND Heremans, J. F. 1965. Immunochemical quantitation of antigens by single radial immunodiffusion. Immunochemistry, 2, 235.

ØRskov, F. 1956. Studies on E. coli $\mathrm{K}$ antigens. I. On the occurrence of B antigens. Acta path. microbiol. scand., 39, 147.

ØRSKOV, I. AND ØRSKOV, F. 1970. The K antigens of Escherichia coli. Re-examination and re-evaluation of the nature of L antigens. Acta path. microbiol. scand., B78, 593. 
ØRSKOv, F., ØRSKOV, I., JANN, B. AND JANN, K. 1971. Immunoelectrophoretic patterns of extracts from all Escherichia coli $\mathrm{O}$ and $\mathrm{K}$ antigen test strains; correlation with pathogenicity. Acta path. microbiol. scand., B79, 142.

OuCHTERLONY, O. 1958. Diffusion-in-gel methods for immunological analysis. In Progress in allergy, vol. 5, edited by P. Kallós, Basel and New York, p. 1.

Rude, E. AND Goebel, W. F. 1962. Colicine K. V. The somatic antigen of a noncolicinogenic variant of E. coli K235. J. exp. Med., 116, 73.

Scheerson, R., Bradshaw, M., Whisnant, J. K., Myerowitz, R. L., Parke, J. C. and RoBbiNs, J. B. 1972. An Escherichia coli antigen cross-reactive with the capsular polysaccharide of Haemophilus influenzae type b. Occurrence among known serotypes, and immunochemical and biologic properties of $E$. coli antisera toward $H$. influenzae type b. J. Immun., 108, 1551.

SCHLECHT, S. AND WeSTPHAL, O. 1966. Wachstum und Lipopolysaccharid (O-antigen)Gehalt von Salmonellen bei Zuchtung auf Agarnahrboden. Zentbl. Bakt. ParasitKde, I. Abt. Orig., 200, 241.

SOJKA, W. J. 1965. Escherichia coli in domestic animals and poultry. Farnham Royal, Buckinghamshire, pp. 205 and 163.

SoJkA, W. J. AND CARNAGHAN, R. B. A. 1961. Escherichia coli infection in poultry. Res. vet. Sci., $2,340$.

VAHLNE, G. 1945. Serological typing of the colon bacteria, with special reference to the occurrence of $B$. coli in man under normal and pathological conditions, particularly in appendicitis. Acta path. microbiol. scand., Suppl. 62, Lund.

Work, E. 1971. Production, chemistry and properties of bacterial pyrogens and endotoxins. In Pyrogens and fever, (CIBA Foundation Symposium), edited by G. E. W. Wolstenholme and J. Birch, Edinburgh, p. 23. 